Research Article

\title{
Reduction of Groundwater Buoyancy on the Basement in Weak-Permeable/Impervious Foundations
}

\author{
Jikai Zhou (ㅁ), Chenghuan Lin, Chen Chen, and Xiyao Zhao \\ College of Civil and Transportation Engineering, Hohai University, Nanjing 210024, China \\ Correspondence should be addressed to Jikai Zhou; zhoujikaihhu@hotmail.com
}

Received 26 June 2019; Accepted 24 October 2019; Published 29 November 2019

Academic Editor: Hayri Baytan Ozmen

Copyright (c) 2019 Jikai Zhou et al. This is an open access article distributed under the Creative Commons Attribution License, which permits unrestricted use, distribution, and reproduction in any medium, provided the original work is properly cited.

\begin{abstract}
At present, groundwater buoyancy is directly calculated by Archimedes' principle for the antifloating design of underground structures. However, this method may not be applicable to weak-permeable/impervious soils, e.g., clayey foundations, because there is a significant difference between the groundwater buoyancy obtained from field measurements and that calculated by Archimedes' principle. In order to determine whether the method of calculating groundwater buoyancy in weak-permeable/ impervious soil layers by Archimedes' principle is reasonable, this paper investigated the groundwater buoyancy on the basement in such foundations through laboratory model tests. The following factors that may influence the magnitude of groundwater buoyancy were investigated: change of groundwater level, duration of pore water pressure, and buried depth of the basement. In this study, model test results show that the groundwater buoyancy obtained from measurements is evidently lower than that calculated by Archimedes' principle. Reduction extent can be expressed by a "reduction coefficient," which can be calculated by a fitting formula. Moreover, experimental groundwater buoyancy increases with the increase in the groundwater level, and it almost does not change with the growth of duration of pore water pressure. Reduction coefficient ranges between 0.25 and 0.52 depending on different buried depths of the basement. In general, experimental groundwater buoyancy decreases with the increase in the buried depth of the basement.
\end{abstract}

\section{Introduction}

The antifloating design is related to the safety and stability of underground structures; so it is a significant aspect in the design of underground engineering. Underground garages and underground pipe galleries in areas with high groundwater level may be uplifted due to high buoyancy [1-4]; so it is very important to estimate the buoyancy acting on underground structures reasonably, particularly in complicated hydrological and geological conditions.

Sand liquefaction during earthquakes can lead to a sudden increase in the buoyancy, and it may cause serious damages to underground structures [5-7]. In recent years, many methods have been used to investigate the uplift mechanism of underground structures caused by sand liquefaction, including shaking table tests [8], the fully coupled dynamic finite element method $[9,10]$, and dynamic centrifuge tests [11]. Different factors that may affect the stability of a shallow foundation have been investigated, such as reduction of excess pore water pressure [8], deformation of backfill soils and original soils [8], and size of the underground structure [11]. Researchers have also done a lot of work to investigate the relationship between seepage flow and pore water pressure [12-18]. Seepage flow has a great effect on the pore water pressure which influences the magnitude of the buoyancy in underground engineering [16]. Both sand liquefaction-induced uplift and seepage flow's influence on groundwater buoyancy have gotten great attention, but less effort has been made to fully evaluate the buoyancy of underground structures subjected to instantaneous and sustained hydrostatic pressures.

In the absence of seepage, Archimedes' principle is usually used to calculate the buoyancy acting on underground structures. This method is very suitable for sandy soil foundation, particularly when the groundwater level can be reasonably determined. However, the interaction between soil 
particles and groundwater at a microlevel may lead to a decrease in buoyancy for weak-permeable/impervious soils, e.g., cohesive soils $[19,20]$. Some researchers hold different opinions on it [21-24], but many test results showed that the measured buoyancy acting on underground structures is lower than that calculated by Archimedes' principle [25-30]. Although finite element methods can help solve many problems in underground engineering, including mesh optimization of complex drainage systems [31], saturated-unsaturated seepage of hydraulic structures [32], and material nonlinearity and soil-pile interaction for fiber-reinforced polymer floating piles [33], experimental investigation is still indispensable. Field measurement can obtain the results under the actual hydrological and geological conditions without considering the simplification of the boundary conditions of the model, which helps solve practical problems [34], but it is expensive and its results are difficult to analyze due to the coupling of multiple factors. Conversely, laboratory tests can control the boundary conditions conveniently, reduce the influence of interference factors, and help clarify the mechanism $[2-4,29,30,35,36]$; so it is attractive.

Considering the lack of systematic investigation on the groundwater buoyancy of underground structures in cohesive soils subjected to hydrostatic pressures, further studies are necessary. The purpose of this paper is to achieve the mechanism and the distribution law of groundwater buoyancy on the basement in weak-permeable/impervious soils, particularly in areas with high groundwater level. By conducting laboratory model tests, the relationship among the groundwater buoyancy, the change of groundwater level, the duration of pore water pressure, and the buried depth of the basement are all obtained, and finally the reduction extent of buoyancy can be easily estimated. This provides an important reference for the antifloating design of underground structures, which helps reduce the uncertainties and costs.

\section{Experimental Program}

It is very difficult to measure the change of groundwater level and the change of pore water pressure in time and accurately due to the influencing factors, e.g., complex hydrological and geological conditions, precipitation weather, and evaporation of surface soil water. Therefore, the laboratory model test was chosen to simulate the hydrological and geological conditions on site. Boundary conditions around the basement can be easily changed for a specific purpose of the testing, which is beneficial to the analysis of test results. In addition, laboratory model tests may help obtain stable measured data in a short time and shorten each testing cycle.

2.1. Experimental Setup and Materials. The container filled with soil samples is an open cylindrical plastic water tank with an outer diameter of $1040 \mathrm{~mm}$, a height of $1150 \mathrm{~mm}$, and a wall thickness of $10 \mathrm{~mm}$. When loading soil samples and adding water, the accuracy of measured data was not affected by excessive "drum" deformation of its sidewall. Taking into account the influencing factors, such as stiffness and shape, an open cylindrical stainless steel bucket with an outer diameter of $300 \mathrm{~mm}$, a height of $600 \mathrm{~mm}$, and a thickness of $0.7 \mathrm{~mm}$ was chosen as the model bucket. This could effectively avoid the problem of "concave" deformation on the sidewalls of a square box. As shown in Figure 1, the strain type microearth pressure cell and the strain type micropore water pressure transducer were both customized products, and their basic parameters are shown in Table 1. The accuracy of this model test could be guaranteed by using microinstruments with high precision. Data acquisition equipment also included a static resistance strain gauge and other auxiliary equipment.

Because the permeability coefficient of bentonite is extremely low, it is usually used as a water-repellent layer or a water-stopping layer in a geotechnical test. In light of this, it is also an ideal material for simulating weak-permeable/ impervious foundations. At last, the bentonite produced in Tangshan town, Nanjing City, was chosen as the foundation soil. Basic parameters of the soil sample are shown in Table 2. The purpose of this experiment was to study the reduction extent of groundwater buoyancy on basements under high groundwater level in general, and not to consider the effect of the structured soil on the experimental results, so remolded soil was used instead of undisturbed soil to be tested. The permeability coefficient of remolded soil sample was $1.17 \times 10^{-9} \mathrm{~m} / \mathrm{s}$. In order to simulate the water-bearing state of the foundation soil in high groundwater level areas, the soil sample was submerged under water for 30 days long to make sure that it is near full saturation.

2.2. Experimental Procedures. A schematic diagram of the test setup is shown in Figure 2. To facilitate the discussion later, it was agreed that the bottom of the model bucket was used as the reference surface in each testing, that was, the zero point of the water head in that testing. The experiment was conducted 5 times under the buried depth of $5 \mathrm{~cm}$, $10 \mathrm{~cm}, 15 \mathrm{~cm}, 20 \mathrm{~cm}$, and $25 \mathrm{~cm}$, respectively. The following testing procedures are included: (1) The plastic water tank was placed on the flat ground and was filled with the bentonite sample layer by layer. (2) When the soil sample was filled to the predetermined height, water was added to the model bucket to a water level of $50 \mathrm{~cm}$. Then, the model bucket was placed vertically at the center of the soil sample to start prepressing, and let it stand for 24 hours until the soil sample is fully consolidated. (3) Three microearth pressure cells and three micropore water pressure transducers were connected to the static resistance strain gauge, and its power was turned on to preheat instruments (preheating time was more than $30 \mathrm{~min}$ ). (4) After completing the consolidation of the soil sample, the model bucket was removed. Three microearth pressure cells and three micropore water pressure transducers were buried evenly in the central surface of the soil sample, and Vaseline was smeared evenly along the wire to prevent water from flowing into the bottom of the model bucket. After completing the burial, the instrument data were reset. (5) The model bucket was placed gently to ensure that it was vertical (the water level in the model bucket was kept at $50 \mathrm{~cm}$ ). Vaseline was evenly smeared on 


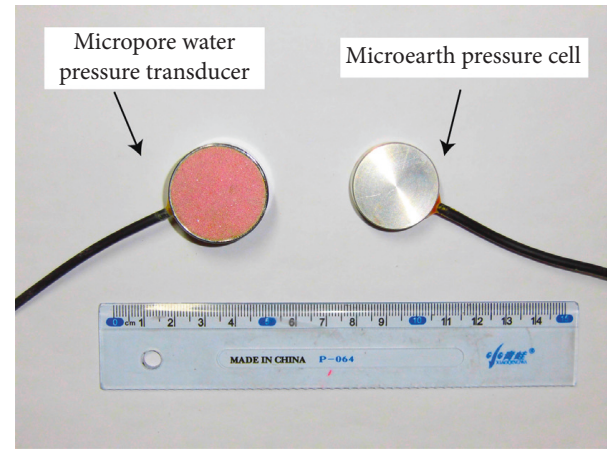

FIGURE 1: Measuring instrument.

TABle 1: Parameters of the sensors.

\begin{tabular}{lccccc}
\hline Sensor & $\begin{array}{c}\text { Range } \\
(\mathrm{kPa})\end{array}$ & $\begin{array}{c}\text { Resolution } \\
(\% \mathrm{~F} \cdot \mathrm{S})\end{array}$ & $\begin{array}{c}\text { Diameter }(\mathrm{mm}) \times \text { thickness } \\
(\mathrm{mm})\end{array}$ & $\begin{array}{c}\text { Resistance } \\
(\Omega)\end{array}$ & $\begin{array}{c}\text { Sensitivity } \\
\text { coefficient }\end{array}$ \\
\hline $\begin{array}{l}\text { Microearth pressure cell } \\
\begin{array}{l}\text { Micropore water pressure } \\
\text { transducer }\end{array}\end{array}$ & $0 \sim 20.00$ & $\leq 0.05$ & $\Phi 28 \times 10$ & 350 & 2.0 \\
\hline
\end{tabular}

TABLE 2: Engineering properties of the soil samples.

\begin{tabular}{lcccccc}
\hline $\begin{array}{l}\text { Natural water } \\
\text { content }(\%)\end{array}$ & $\begin{array}{c}\text { Bulk density } \\
\left(\mathrm{g} / \mathrm{cm}^{3}\right)\end{array}$ & $\begin{array}{c}\text { Specific } \\
\text { gravity, } G_{\mathrm{s}}\end{array}$ & $\begin{array}{c}\text { Permeability } \\
(\mathrm{m} / \mathrm{s})\end{array}$ & $\begin{array}{c}\text { Colloid index } \\
(\mathrm{ml} / 15 \mathrm{~g})\end{array}$ & $\begin{array}{c}\text { Montmorillonite } \\
\text { content }(\%)\end{array}$ & $\begin{array}{c}\text { Swelling capacity } \\
(\mathrm{ml} / \mathrm{g})\end{array}$ \\
\hline 18.4 & 1.82 & 2.73 & $1.17 \times 10^{-9}$ & 32 & 43 & 5.1 \\
\hline
\end{tabular}

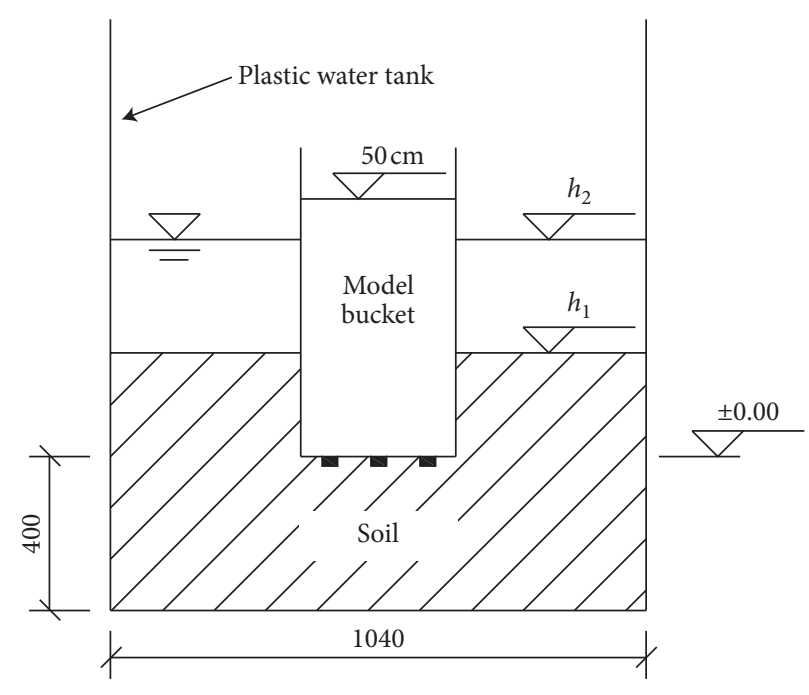

(a)

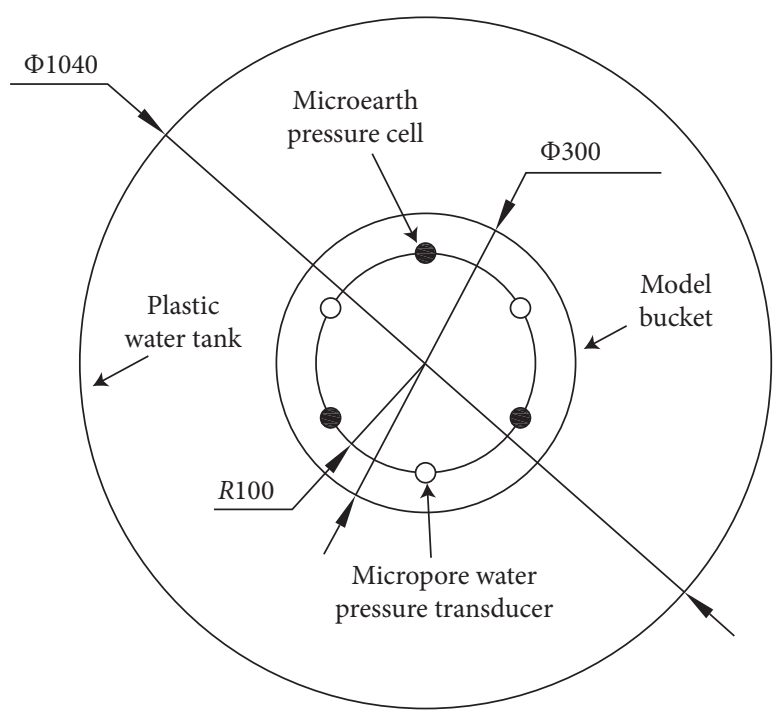

(b)

Figure 2: Schematic diagram of the test setup. (a) Front view (mm). (b) Plan view (mm).

its outer wall, which can prevent water from flowing into its bottom along its outer wall. Then, the soil sample was layered and compacted along its sidewall to a predetermined height $\left(h_{1}\right)$, which represented the buried depth of the model bucket. Data collection began after one hour. At this time, the whole system had reached a relatively stable state. (6) Water was added to the plastic water tank every half an hour to increase the water level in the plastic water tank $\left(h_{2}\right)$ by
$5 \mathrm{~cm}$. After standing for half an hour, the measured data were collected once. During the testing, $h_{2}$ should always be no more than $50 \mathrm{~cm}$, which could ensure that the model bucket has no floating trend. (7) When $h_{2}$ had reached $50 \mathrm{~cm}$, no water was added to the plastic water tank. Thus, both the water level in the plastic water tank $\left(h_{2}\right)$ and the water level in the model bucket were kept unchanged. Then, the measured data were collected every half an hour in the 
next 15 hours. (8) After the previous testing was completed, the experimental site was cleaned up and prepared for the next working condition.

As can be seen from the above testing procedures, Steps (1) to (7) can simulate the change of groundwater buoyancy on the basement of underground structures when the water level increases rapidly, which helps obtain the relationship between groundwater buoyancy and the change of groundwater level. The buoyancy of underground structures subjected to instantaneous hydrostatic pressures can also be evaluated through these steps. Step (8) can simulate the change of groundwater buoyancy on the basement of underground structures when the water level is constant, which can obtain the relationship between groundwater buoyancy and the duration of pore water pressure. Furthermore, comparing the experimental results of different buried depths, the relationship between the groundwater buoyancy and the buried depth of the basement can be obtained.

\section{Results and Discussion}

3.1. Mechanical Analysis. The model test is designed as a nonfloating one, which means that there is no upward trend of the model bucket in each testing process. As a result, the influence of friction between the outer wall of the model bucket and the soil sample on the test results does not need to be taken into account.

The total weight $(G)$ of the model bucket and the water in it can be obtained by calculation. The total reaction force $\left(F_{z}\right)$ and the measured pore water pressure $\left(F_{\mathrm{u}}\right)$ on the bottom of the model bucket can be calculated by the measured data of microearth pressure cells, and micropore water pressure transducers, respectively. According to Archimedes' principle, theoretical groundwater buoyancy $(F)$ on the bottom of the model bucket at different water levels can be computed as

$$
F=\rho A h_{2} g,
$$

where $\rho$ is the density of water, $A$ is the cross-sectional area of the model bucket, and $g$ is the gravitational acceleration.

As can be known from Archimedes' principle, the model bucket is subjected to experimental groundwater buoyancy $\left(F_{1}\right)$, support force from the soil grains $\left(F_{2}\right)$, and total weight $(G)$ in each testing process (Figure 3 ). In the vertical direction, these three forces have the following static equilibrium equation:

$$
G=F_{1}+F_{2} .
$$

The support force from the soil grains $\left(F_{2}\right)$ can be calculated by

$$
F_{2}=F_{\mathrm{z}}-F_{\mathrm{u}}
$$

where $F_{\mathrm{z}}$ is the total reaction force on the bottom of the model bucket and $F_{\mathrm{u}}$ is the measured pore water pressure on the bottom of the model bucket.

Furthermore, the experimental groundwater buoyancy $\left(F_{1}\right)$ can be obtained by combining equation (2) with equation (3).

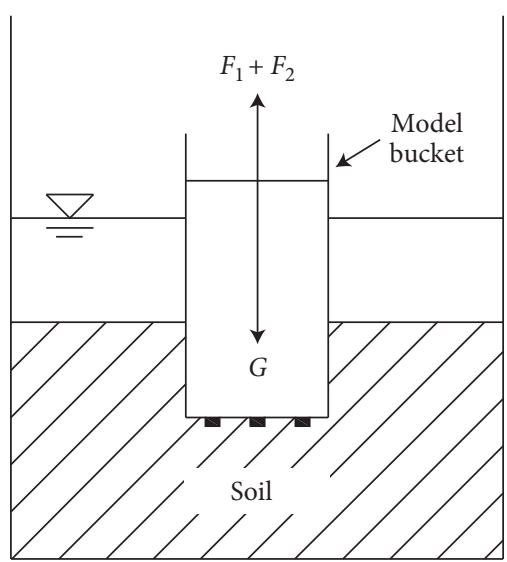

FIGURE 3: Schematic diagram of static balance in vertical direction.

The ratio of experimental groundwater buoyancy $\left(F_{1}\right)$ to theoretical groundwater buoyancy $(F)$ is defined as a "reduction coefficient $(\lambda)$ (dimensionless)," which is used to indicate the reduction extent of groundwater buoyancy $[25,27,29,30]$. The smaller the reduction coefficient $(\lambda)$, the greater the difference between the value of experimental groundwater buoyancy $\left(F_{1}\right)$ and that of theoretical groundwater buoyancy $(F) . \lambda$ can be obtained by the following equation:

$$
\lambda=\frac{F_{1}}{F} .
$$

Similarly, the ratio of experimental groundwater buoyancy $\left(F_{1}\right)$ to measured pore water pressure $\left(F_{\mathrm{u}}\right)$ is defined as a "proportion coefficient $(\Psi)$ (dimensionless)," which is used to indicate the proximity of $F_{1}$ and $F_{\mathrm{u}}$. The larger the proportion coefficient $(\Psi)$, the closer the value of experimental groundwater buoyancy $\left(F_{1}\right)$ is to that of theoretical groundwater buoyancy $(F) . \Psi$ can be obtained by the following equation:

$$
\psi=\frac{F_{1}}{u A},
$$

where $u$ is the pore water pressure measured by the micropore water pressure transducers.

\subsection{Groundwater Buoyancy Varies with Different Ground-} water Levels. According to the foregoing testing procedures, the variation of experimental groundwater buoyancy $\left(F_{1}\right)$ with the groundwater level under different buried depths of the model bucket can be obtained, as shown in Figure 4 .

According to Figure 4, the experimental groundwater buoyancy $\left(F_{1}\right)$ increases linearly with the increase of groundwater level when the buried depth of the model bucket is $5 \mathrm{~cm}, 10 \mathrm{~cm}, 15 \mathrm{~cm}, 20 \mathrm{~cm}$, and $25 \mathrm{~cm}$, respectively. However, its growth rate is obviously less than that of the theoretical groundwater buoyancy $(F)$. When the groundwater level is the same, values of the experimental groundwater buoyancy $\left(F_{1}\right)$ under different buried depths are obviously different, and they generally show a rule of decreasing with the increase of buried depth. 


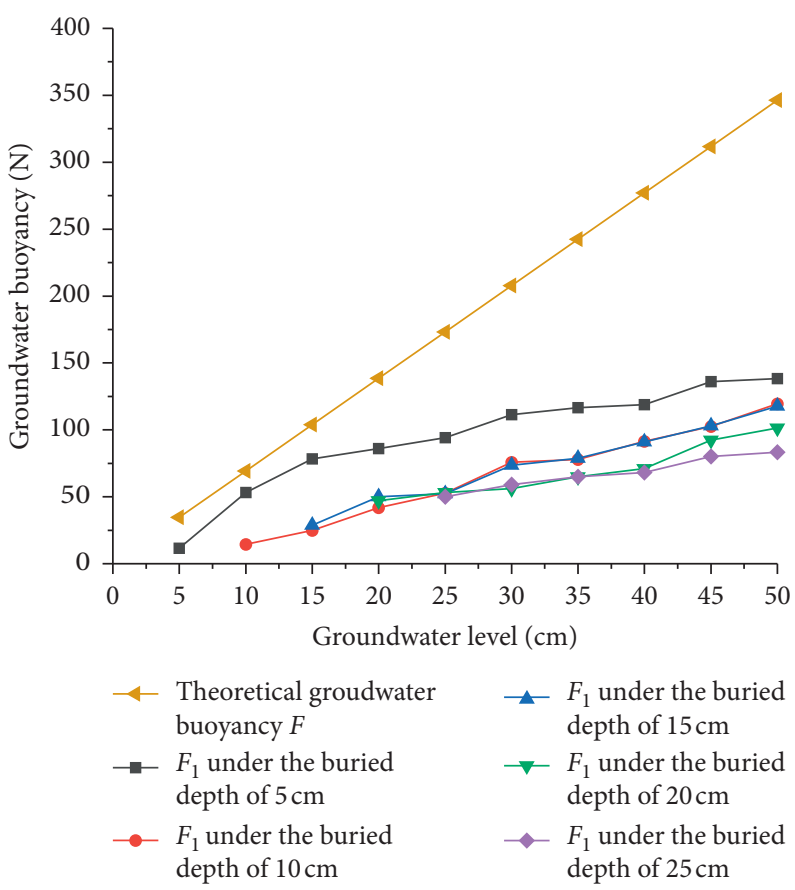

FIGURE 4: Variation of experimental groundwater buoyancy with the groundwater level under different buried depths.

As illustrated in Figure 5, five straight lines are fitted by values of the experimental groundwater buoyancy $\left(F_{1}\right)$ under different buried depths of $5 \mathrm{~cm}, 10 \mathrm{~cm}, 15 \mathrm{~cm}, 20 \mathrm{~cm}$, and $25 \mathrm{~cm}$, respectively. Table 3 summarizes the basic parameters of the fitting formulas. According to equation (4), the reduction coefficient $(\lambda)$ can also be calculated by

$$
\lambda=\frac{a}{\rho A g},
$$

where $a$ is the slope of the fitted line.

As indicated in Figure 5, values of the experimental groundwater buoyancy $\left(F_{1}\right)$ have a good linear relationship with the change of groundwater level under different buried depths of $5 \mathrm{~cm}, 10 \mathrm{~cm}, 15 \mathrm{~cm}, 20 \mathrm{~cm}$, and $25 \mathrm{~cm}$, respectively, which can be characterized by a linear function. As listed in Table 3 , the reduction coefficient $(\lambda)$ is distributed in the range of $0.25 \sim 0.47$ in virtue of different buried depths of the model bucket, which indicates that there is a great reduction of the groundwater buoyancy. The reduction coefficient $(\lambda)$ when the buried depth is $10 \mathrm{~cm}$ is slightly smaller than that when the buried depth is $15 \mathrm{~cm}$, which may be caused by test errors or bias. Furthermore, as detailed in Figure 6, a function relationship between the reduction coefficient $(\lambda)$ and the buried depth of the model bucket is fitted. As can be seen, the reduction coefficient $(\lambda)$ can be calculated by the equation below:

$$
\lambda=0.912\left(1+h_{1}\right)^{-0.387} .
$$

According to equation (7), in weak-permeable/impervious foundations, the reduction coefficient $(\lambda)$ decreases dramatically with the increase in the buried depth $\left(h_{1}\right)$ at the initial stage; that is to say, the reduction extent of groundwater buoyancy is significantly increased. After that, the rate of decrease gradually slows down. It is worth mentioning that the reduction coefficient $(\lambda)$ obtained from the fitted curve is 0.912 when the buried depth of the basement is $0 \mathrm{~cm}$ (this means that the model bucket is placed directly on the surface of the soil layer). This result is similar to that of 0.95 obtained by Zhang [22] on a clayey foundation, and it is also similar to that of 0.973 on a kaolin foundation and that of 0.959 on a montmorillonite foundation obtained by Rong [23, 24], respectively. However, soil properties are inhomogeneous by nature, and this has a great effect on the analysis of practical engineering problems $[37,38]$. Moreover, owing to different test methods and permeabilities of the soils, there are slight differences in the results. Therefore, it is not reasonable to conclude that there is no reduction in groundwater buoyancy in weak-permeable/impervious foundations based solely on the experimental result of a buried depth of $0 \mathrm{~cm}$.

As detailed in Figure 7, the proportion coefficient $(\Psi)$ fluctuates slightly at a lower groundwater level and tends to be stable at a higher water level. Finally, the proportion coefficient $(\Psi)$ of each buried depth is gradually stabilized at 0.85 . Because the measured value itself is small at the beginning of the test, even a small test error may cause a large data fluctuation of the proportion coefficient $(\Psi)$. In general, the variation of the experimental groundwater buoyancy $\left(F_{1}\right)$ is consistent with that of the measured pore water pressure $\left(F_{\mathrm{u}}\right)$, and the values of the two are relatively close. For convenience, the measured pore water pressure $\left(F_{\mathrm{u}}\right) \mathrm{can}$ be used to characterize the experimental groundwater buoyancy $\left(F_{1}\right)$.

As can be seen from the above test results, the variation of experimental groundwater buoyancy $\left(F_{1}\right)$ on the basement in weak-permeable/impervious foundations is consistent with the change of groundwater level, but it is obviously smaller 


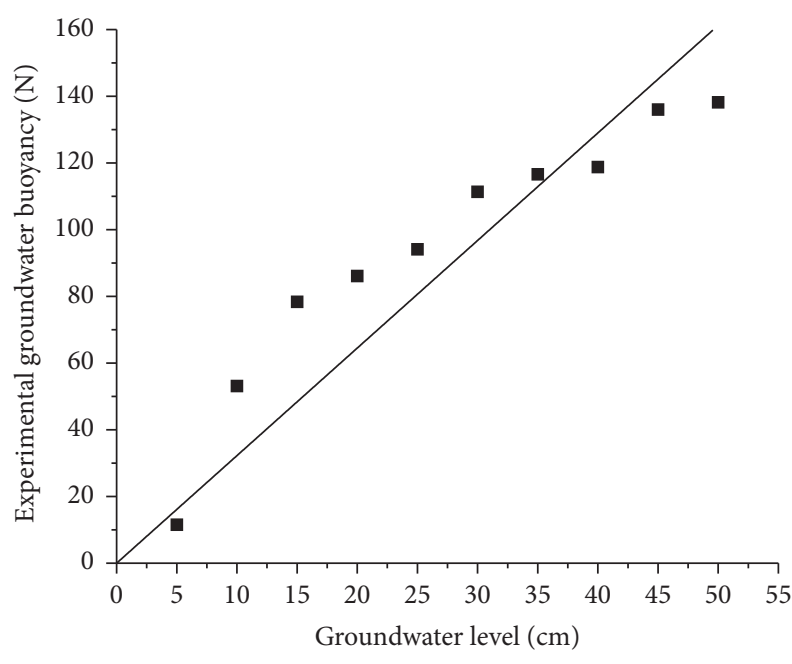

- Experimental groundwater buoyancy $F_{1}$ $-F_{1}=3.225 h_{2}$, Adj. $R^{2}=0.968$

(a)

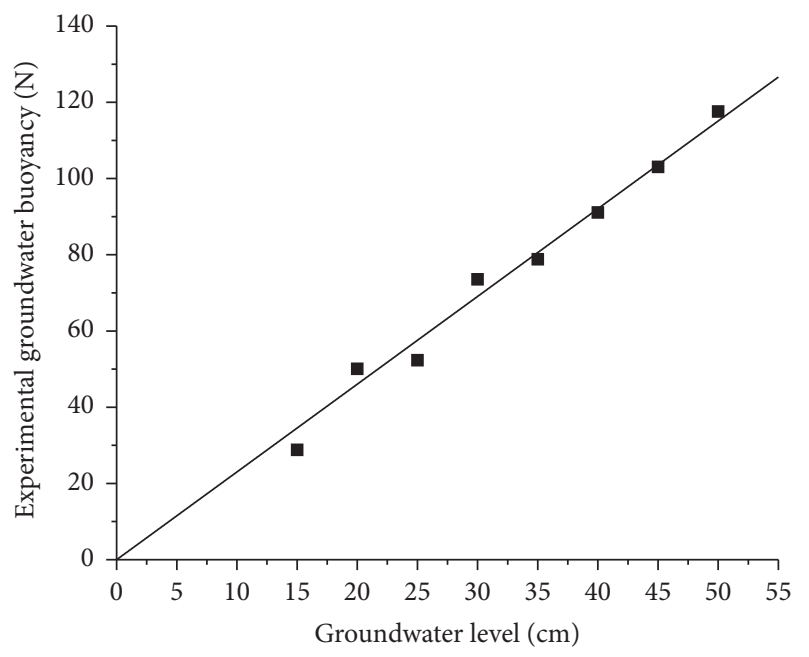

- Experimental groundwater buoyancy $F_{1}$ — $F_{1}=2.302 h_{2}$, Adj. $R^{2}=0.998$

(c)

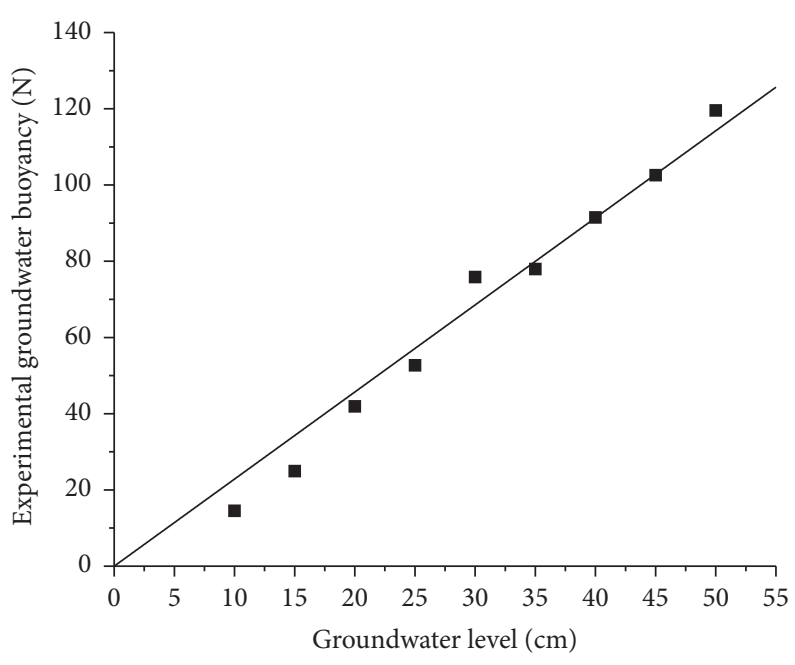

- Experimental groundwater buoyancy $F_{1}$ $F_{1}=2.285 h_{2}$, Adj. $R^{2}=0.994$

(b)

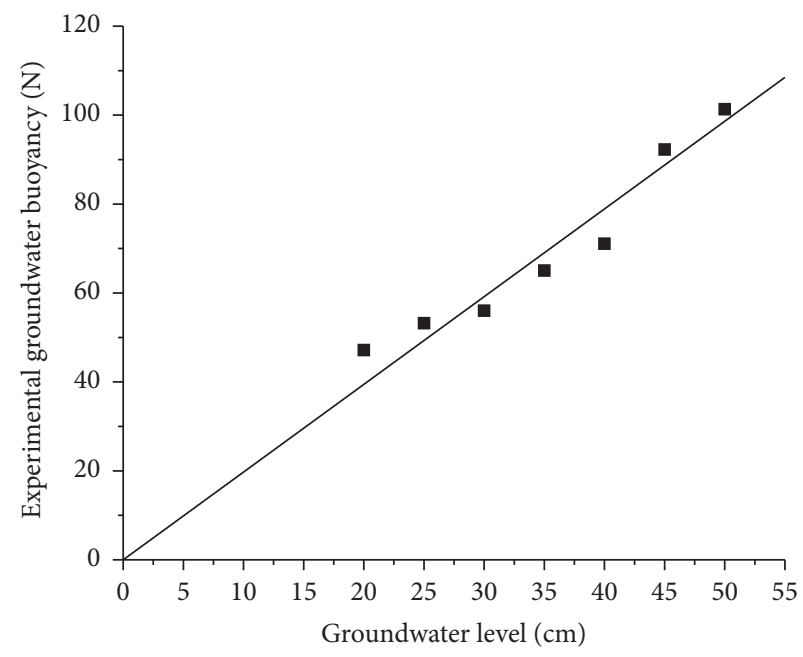

- Experimental groundwater buoyancy $F_{1}$ - $F_{1}=1.973 h_{2}$, Adj. $R^{2}=0.994$

(d)

Figure 5: Continued. 


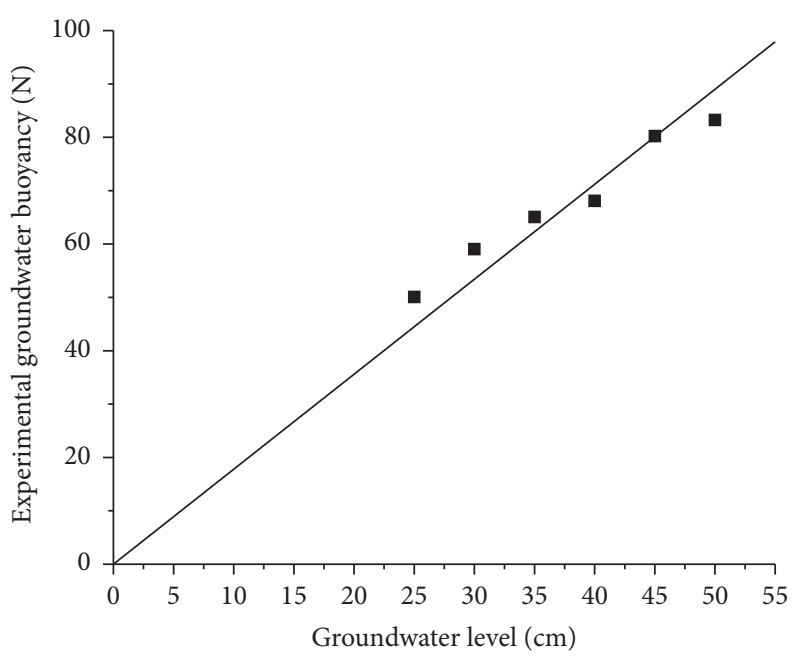

- Experimental groundwater buoyancy $F_{1}$

$F_{1}=1.780 h_{2}$, Adj. $R^{2}=0.995$

(e)

FIGURE 5: Fitting line of the experimental groundwater buoyancy with the groundwater level under different buried depths: (a) $5 \mathrm{~cm}$, (b) $10 \mathrm{~cm}$, (c) $15 \mathrm{~cm}$, (d) $20 \mathrm{~cm}$, and (e) $25 \mathrm{~cm}$.

TABle 3: Parameters of the fitting formulas.

\begin{tabular}{lccc}
\hline Groundwater level $h_{2}(\mathrm{~cm})$ & Slope $a=F_{1} / h_{2}(\mathrm{~N} / \mathrm{cm})$ & Adj. $R^{2}$ & Reduction coefficient $\lambda$ \\
\hline 5 & 3.225 & 0.968 & 0.466 \\
10 & 2.285 & 0.994 & 0.330 \\
15 & 2.302 & 0.998 & 0.332 \\
20 & 1.973 & 0.994 & 0.285 \\
25 & 1.780 & 0.995 & 0.257 \\
\hline
\end{tabular}

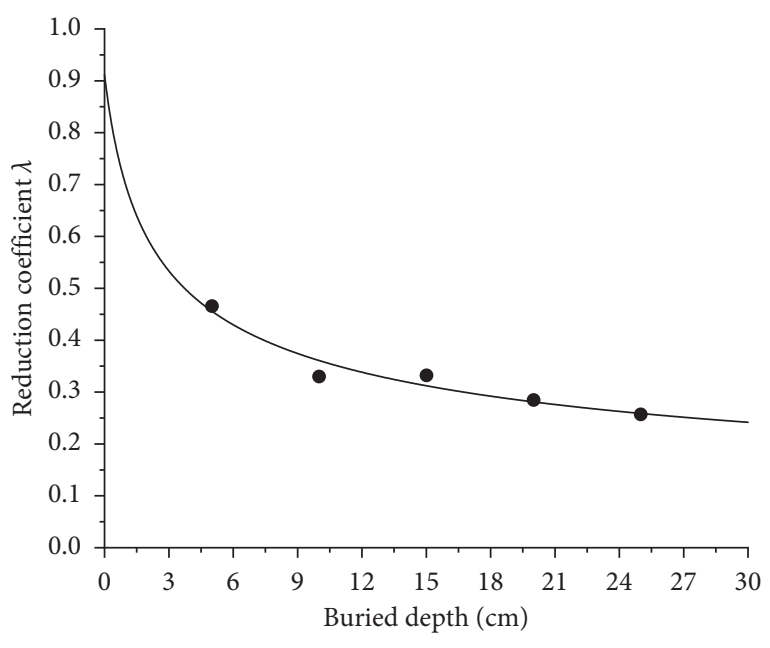

- Reduction coefficient $\lambda$

$\lambda=0.912 \cdot\left(1+h_{1}\right)^{-0.387}$, Adj. $R^{2}=0.923$

FIGURE 6: Function relationship between reduction coefficient $\lambda$ and buried depth of the basement.

than the theoretical groundwater buoyancy $(F)$, which means that there is a great reduction. The main causes are as follows: (1) The clay contains a lot of fine particles, and water is

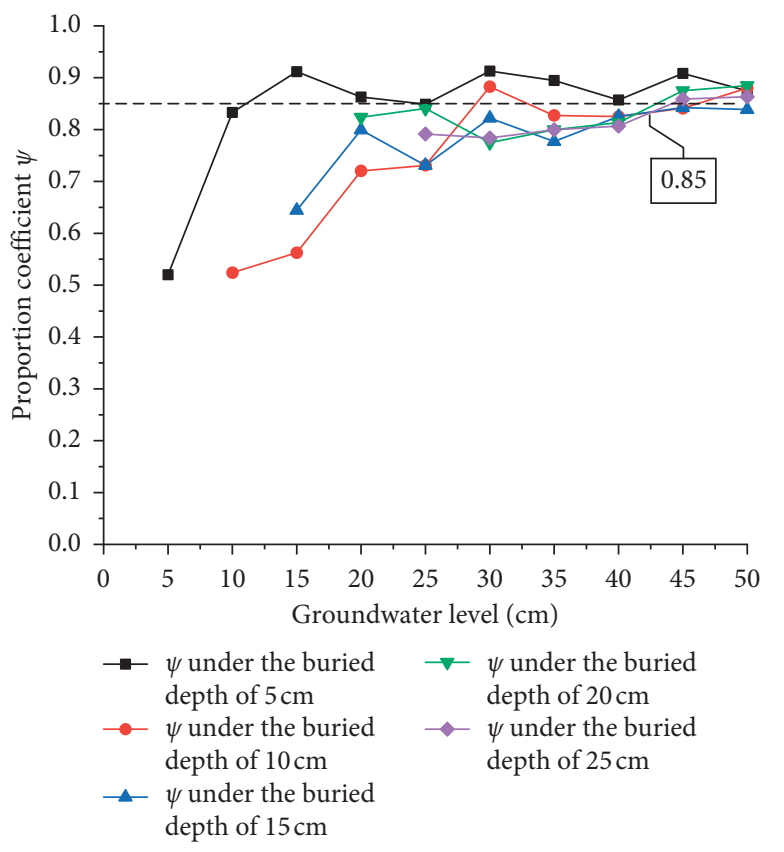

FIgURE 7: Variation of proportion coefficient $\Psi$ with the groundwater level under different buried depths. 
adsorbed on its surface by the electrostatic interaction, which contributes to a large viscous resistance. Only when the hydraulic gradient reaches a critical hydraulic gradient can the permeation occur, which leads to a partial loss in the pore pressure transmission between the pores of soil particles. (2) The pores in the clay are very small and their connectivity is poor, which leads to a poor water permeability and a slow penetration rate of the clay. Therefore, the change of groundwater level in a short time period is sometimes difficult to cause the variation of experimental groundwater buoyancy $\left(F_{1}\right)$ and that of measured pore water pressure $\left(F_{\mathrm{u}}\right)$, which means that the variations of the two are distinctly lagging. (3) With the increase of buried depth of the basement, the adsorbed water in the clay increases and the viscous resistance increases, so the hydraulic gradient needs to become higher to penetrate. In addition, the connectivity of the pores in the clay may be worse, which leads to a further deterioration of the water permeability of the clay, and thus loss in the pore pressure transmission between the pores of soil particles may be increased, and the variation of experimental groundwater buoyancy $\left(F_{1}\right)$ and that of measured pore water pressure $\left(F_{\mathrm{u}}\right)$ could be more lagging. (4) When groundwater buoyancy is calculated by the pore water pressure on the bottom surface of the model bucket, the action area of groundwater buoyancy should be reduced $[27,29,30]$. The partial area of the bottom surface is occupied by soil particles (Figure 8), but it is considered that the bottom area is entirely occupied by pore water when calculating the theoretical groundwater buoyancy $(F)$, so the calculated groundwater buoyancy value will be larger. (5) Although the soil samples have been submerged under water for 30 days long to get a fully saturated state, its degree of saturation might not reach $100 \%$ [29].

\subsection{Groundwater Buoyancy Varies with Different Durations of} Groundwater Pressure. According to the foregoing testing procedures, the variation of experimental groundwater buoyancy $\left(F_{1}\right)$ with the duration of groundwater pressure under different buried depths of the model bucket can be obtained, as shown in Figure 9.

As illustrated in Figure 9, the value of experimental groundwater buoyancy $\left(F_{1}\right)$ is basically stable with the increase of the time period of groundwater pressure when the buried depth of the basement is $5 \mathrm{~cm}, 10 \mathrm{~cm}, 15 \mathrm{~cm}$, $20 \mathrm{~cm}$, and $25 \mathrm{~cm}$, respectively. Its initial value is not much different from its final value (the testing lasted 15 hours), and its final value is still distinctly smaller than that of the theoretical groundwater buoyancy $(F)$. When the duration of groundwater pressure and the groundwater level are both the same, values of the experimental groundwater buoyancy $\left(F_{1}\right)$ under different buried depths are different, and they generally show a rule of decreasing with the increase of the buried depth.

It can be seen from Figure 10 that the reduction coefficient $(\lambda)$ is almost constant during the test period. Meanwhile, it ranges between 0.25 and 0.52 with different buried depths at the end of the test. It is evident that the experimental groundwater buoyancy $\left(F_{1}\right)$ still has a large reduction extent after the increase of duration of groundwater pressure and

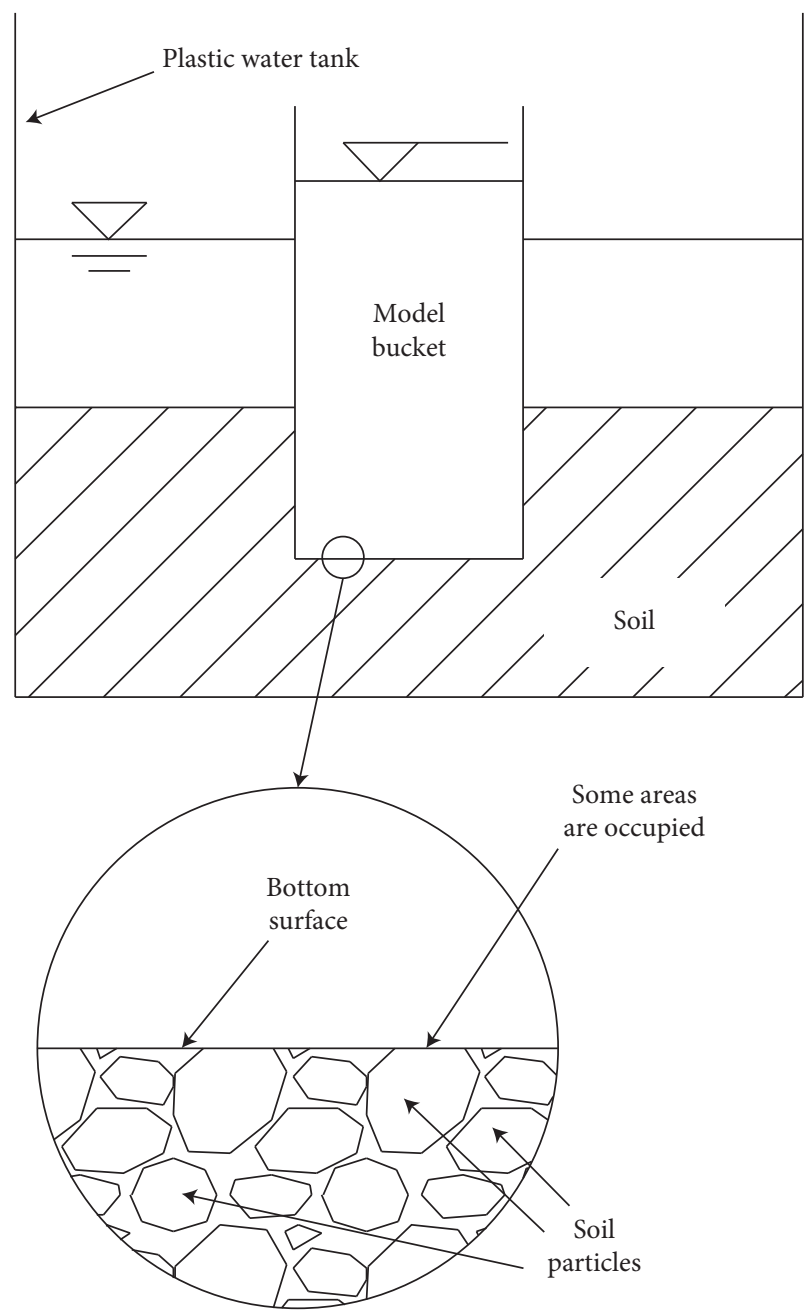

FIGURE 8: Local enlarged drawing of bottom surface of the model bucket.

that the reduction extent is almost unchanged. When the duration of groundwater pressure and the groundwater level are both the same, the values of reduction coefficient $(\lambda)$ under different buried depths are different, and they on the whole show a rule of decreasing with the increase of the buried depth. Therefore, the reduction coefficient $\lambda$ of a certain buried depth under the action of long-term pore water pressure can still be calculated by Equation (7). As detailed in Figure 11, the proportion coefficient $(\Psi)$ is in a roughly stable state of slight volatility during the test period, and it is distributed in the range of $0.84 \sim 0.94$ at the end of the testing. This indicates that the variation of experimental groundwater buoyancy $\left(F_{1}\right)$ is still consistent with that of measured pore water pressure $\left(F_{\mathrm{u}}\right)$ with the increase of duration of groundwater pressure, and the values of the two are closer. In view of the above, it is suggested that the measured pore water pressure $\left(F_{\mathrm{u}}\right)$ may be used to characterize the experimental groundwater buoyancy $\left(F_{1}\right)$.

From the above experimental results, during the test period, the value of experimental groundwater buoyancy $\left(F_{1}\right)$ on the basement in weak-permeable/impervious foundations is almost constant with the increase of duration of groundwater 


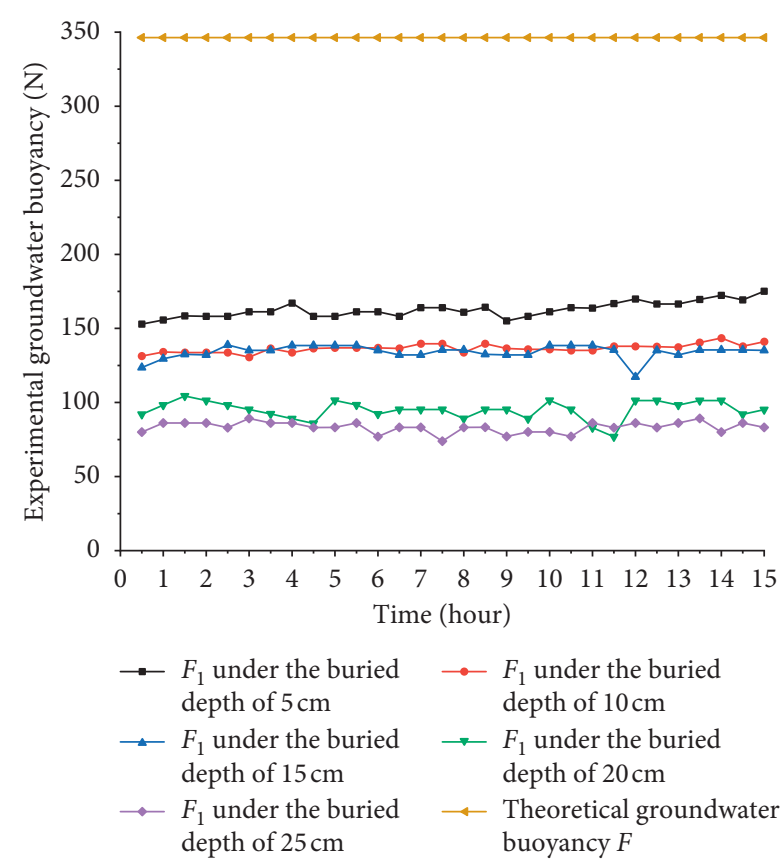

FIGURE 9: Variation of experimental groundwater buoyancy with the action time of groundwater pressure under different buried depths.

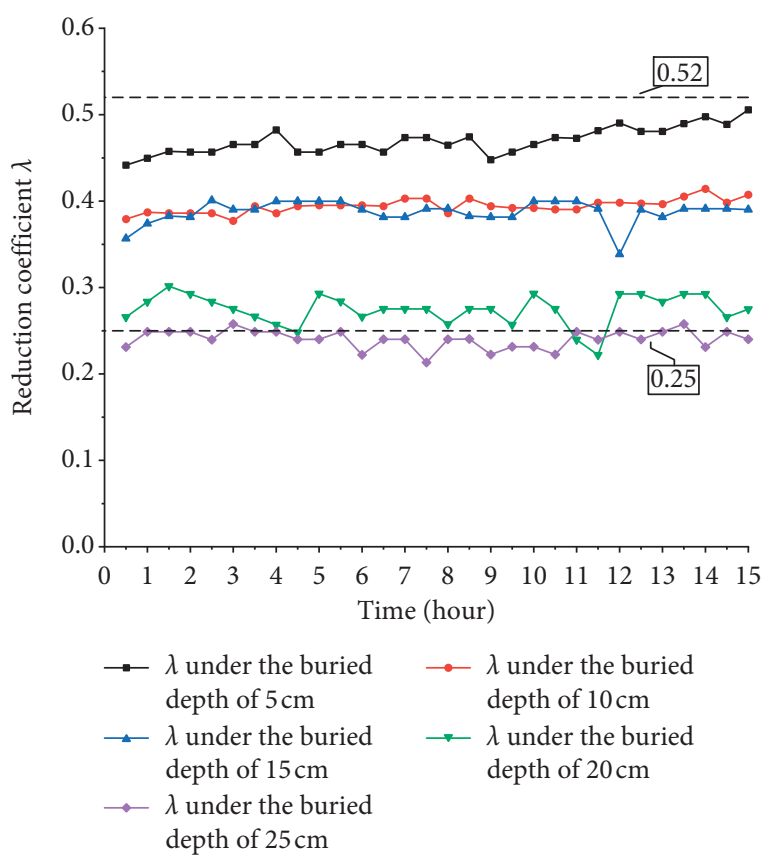

Figure 10: Variation of reduction coefficient $\lambda$ with the action time of groundwater pressure under different buried depths.

pressure, which is significantly smaller than that of the theoretical groundwater buoyancy $(F)$. It indicates that the seepage of groundwater in a poorly permeable foundation is extremely slow and that there is a large time lag in the variation of experimental groundwater buoyancy $\left(F_{1}\right)$ and that of measured pore water pressure $\left(F_{\mathrm{u}}\right)$. In addition, although this test is a nonfloating one, it can be found that there will be a floating

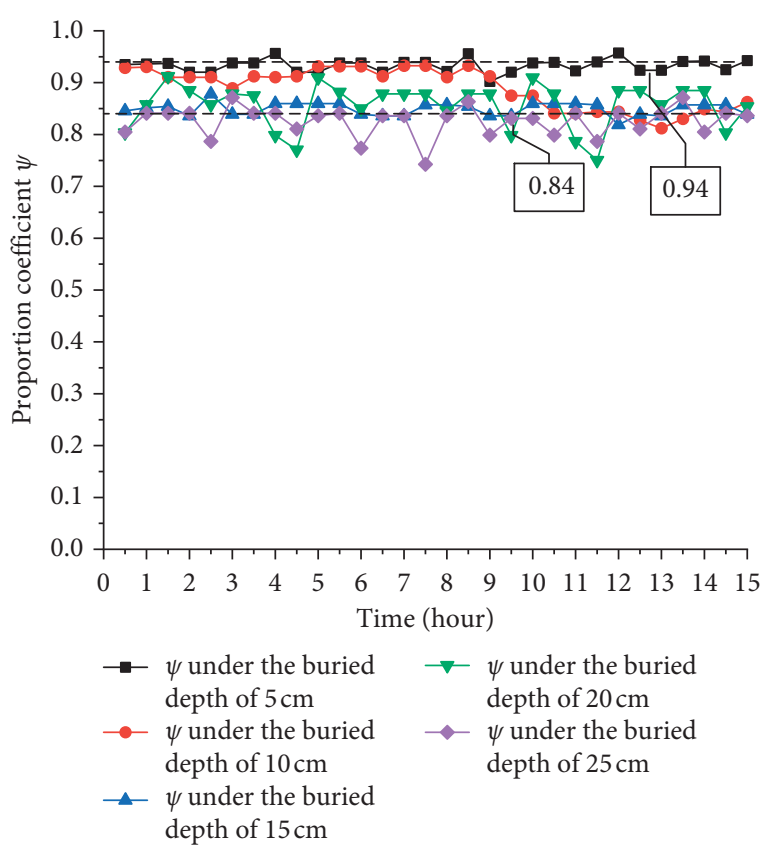

Figure 11: Variation of proportion coefficient $\Psi$ with the action time of groundwater pressure under different buried depths.

trend when the groundwater buoyancy of the model bucket is greater than its self-weight. At this time, a quite small "gap" that between the top of the clayey foundation and the bottom of the model bucket will be generated. This means that there will be "negative excess pore water pressure" between the top of the clay layer and the bottom of the model bucket. Owing to the poor water permeability of the clayey soil, the negative excess pore water pressure is extremely hard to dissipate [39], and thus it serves as "suction" to the foundation and helps reduce the experimental groundwater buoyancy $\left(F_{1}\right)$. In view of this, the time-lag effect of pore water pressure diffusion should be taken into account when applying the effective stress principle in engineering [40]. Therefore, even if the basement in weakpermeable/impervious foundations will be subjected to groundwater for a long time, its groundwater buoyancy can be appropriately reduced according to the actual situation.

\section{Conclusions}

The groundwater buoyancy on the basement in weak-permeable/impervious foundations under high groundwater level was investigated by conducting laboratory model tests. The relationship among groundwater buoyancy, the change of groundwater level, the duration of groundwater pressure, and the buried depth of the basement are all obtained. Furthermore, a function expression of the reduction coefficient $(\lambda)$ and the buried depth $\left(h_{1}\right)$ of the basement was fitted. The following conclusions were drawn: (1) With the increase of groundwater level, the value of experimental groundwater buoyancy $\left(F_{1}\right)$ increases, but there is a large reduction compared to the theoretical groundwater buoyancy $(F)$, and the reduction coefficient $(\lambda)$ decreases with the increase of buried depth of the basement. (2) With the increase of duration of groundwater pressure, the value of 
experimental groundwater buoyancy $\left(F_{1}\right)$ is almost unchanged, and there is still a large reduction extent. The reduction coefficient $(\lambda)$ still decreases with the increase of buried depth of the basement. (3) Under the same condition of both the duration of groundwater pressure and the groundwater level, values of the experimental groundwater buoyancy $\left(F_{1}\right)$ under different buried depths of the basement are different. In general, they decrease with the increase of buried depth. (4) The measured pore water pressure $\left(F_{\mathrm{u}}\right)$ could be used to characterize the experimental groundwater buoyancy $\left(F_{1}\right)$.

\section{Notation}

A: Cross-sectional area of the model bucket

$a$ : Slope of the fitted line $\left(a=F_{1} / h_{2}\right)$

$F$ : Theoretical groundwater buoyancy calculated by Archimedes' principle

$F_{1}$ : Experimental groundwater buoyancy on the bottom of the model bucket

$F_{2}$ : Support force from the soil grains on the bottom of the model bucket

$F_{\mathrm{u}}$ : Measured pore water pressure on the bottom of the model bucket

$F_{\mathrm{z}}$ : Total reaction force on the bottom of the model bucket

G: Total weight of the model bucket and the water in it

$G_{s}$ : Specific gravity

$g$ : Gravitational acceleration

$h_{1}$ : Buried depth of the model bucket

$h_{2}$ : Water level in the plastic water tank

$u$ : Pore water pressure measured by the micropore water pressure transducers

$\lambda$ : Reduction coefficient

$\rho$ : Density of water

$\Psi$ : Proportion coefficient.

\section{Data Availability}

The data used to support the findings of this study are obtained directly from the tests and included within the article.

\section{Conflicts of Interest}

The authors declare that there are no conflicts of interest regarding the publication of this paper.

\section{Acknowledgments}

This research was funded by the National Key Research and Development Program of China (Grant no. 2017YFC0404902), National Natural Science Foundation of China (Grant no. 51479048), Postgraduate Research \& Practice Innovation Program of Jiangsu Province (Grant no. SJKY19_0457), the Fundamental Research Funds for the Central Universities (Grant no. 2019B73914), and the Science and Technology Project of Zhejiang Water Conservancy Department (Grant no. RA1503). The authors gratefully acknowledge the financial support.

\section{References}

[1] I. H. Wong, "Methods of resisting hydrostatic uplift in substructures," Tunnelling and Underground Space Technology, vol. 16, no. 2, pp. 77-86, 2001.

[2] H. E. Acosta-Martinez, S. M. Gourvenec, and M. F. Randolph, "An experimental investigation of a shallow skirted foundation under compression and tension," Soils and Foundations, vol. 48, no. 2, pp. 247-254, 2008.

[3] S. Gourvenec, H. E. Acosta-Martinez, and M. F. Randolph, "Experimental study of uplift resistance of shallow skirted foundations in clay under transient and sustained concentric loading," Géotechnique, vol. 59, no. 6, pp. 525-537, 2009.

[4] H. E. Acosta-Martinez, S. Gourvenec, and M. F. Randolph, "Centrifuge study of capacity of a skirted foundation under eccentric transient and sustained uplift," Géotechnique, vol. 62, no. 4, pp. 317-328, 2012.

[5] H. B. Seed, I. M. Idriss, and I. Arango, "Evaluation of liquefaction potential using field performance data," Journal of Geotechnical Engineering, vol. 109, no. 3, pp. 458-482, 1983.

[6] Y. M. A. Hashash, J. J. Hook, B. Schmidt, J. I.-C. Yao, and C. Yao, "Seismic design and analysis of underground structures," Tunnelling and Underground Space Technology, vol. 16, no. 4, pp. 247-293, 2001.

[7] Y. Huang and M. Yu, "Review of soil liquefaction characteristics during major earthquakes of the twenty-first century," Natural Hazards, vol. 65, no. 3, pp. 2375-2384, 2013.

[8] J. Koseki, O. Matsuo, and Y. Koga, "Uplift behavior of underground structures caused by liquefaction of surrounding soil during earthquake," Soils and Foundations, vol. 37, no. 1, pp. 97-108, 1997.

[9] H. Liu and E. Song, "Seismic response of large underground structures in liquefiable soils subjected to horizontal and vertical earthquake excitations," Computers and Geotechnics, vol. 32, no. 4, pp. 223-244, 2005.

[10] H. Liu and E. Song, "Working mechanism of cutoff walls in reducing uplift of large underground structures induced by soil liquefaction," Computers and Geotechnics, vol. 33, no. 4-5, pp. 209-221, 2006.

[11] S. C. Chian and S. P. G. Madabhushi, "Effect of buried depth and diameter on uplift of underground structures in liquefied soils," Soil Dynamics and Earthquake Engineering, vol. 41, pp. 181-190, 2012

[12] J.-J. Wang, H.-P. Zhang, H.-J. Chai, and J.-G. Zhu, "Seismic passive resistance with vertical seepage and surcharge," Soil Dynamics and Earthquake Engineering, vol. 28, no. 9, pp. 728-737, 2008.

[13] J. D. Rice and J. M. Duncan, "Findings of case histories on the long-term performance of seepage barriers in dams," Journal of Geotechnical and Geoenvironmental Engineering, vol. 136, no. 1, pp. 2-15, 2010.

[14] M. Veiskarami and A. Zanj, "Stability of sheet-pile walls subjected to seepage flow by slip lines and finite elements," Géotechnique, vol. 64, no. 10, pp. 759-775, 2014.

[15] P. J. Santos and P. L. A. Barros, "Active earth pressure due to soil mass partially subjected to water seepage," Canadian Geotechnical Journal, vol. 52, no. 11, pp. 1886-1891, 2015.

[16] G. Attard, T. Winiarski, Y. Rossier, and L. Eisenlohr, "Review: impact of underground structures on the flow of urban groundwater," Hydrogeology Journal, vol. 24, no. 1, pp. 5-19, 2016.

[17] Z. Hu, Z. X. Yang, and S. P. Wilkinson, "Analysis of passive earth pressure modification due to seepage flow effects," 
Canadian Geotechnical Journal, vol. 55, no. 5, pp. 666-679, 2017.

[18] J.-W. Zhang, J. Cao, L. Mu, L. Wang, and J. Li, "Buoyancy force acting on underground structures considering seepage of confined water," Complexity, vol. 2019, Article ID 7672930, 10 pages, 2019.

[19] G. Achari, R. C. Joshi, L. R. Bentley, and S. Chatterji, "Prediction of the hydraulic conductivity of clays using the electric double layer theory," Canadian Geotechnical Journal, vol. 36, no. 5, pp. 783-792, 1999.

[20] P. N. Singh and W. W. Wallender, "Effects of adsorbed water layer in predicting saturated hydraulic conductivity for clays with Kozeny-Carman equation," Journal of Geotechnical and Geoenvironmental Engineering, vol. 134, no. 6, pp. 829-836, 2008.

[21] Y. Cui, J. H. Cui, and S. H. Wu, "Model test of underground structure buoyant," Special Structures, vol. 16, no. 1, pp. 32-36, 1999.

[22] D. Zhang, "Experimental study on anti-floating of underground structures," M. S. thesis, Shanghai Jiao Tong University, Shanghai, China, 2007.

[23] X. N. Rong, R. Q. Xu, and J. Y. Lu, "Physical derivation of effective stress from balance law and experimental evidence," International Journal of Geomechanics, vol. 17, no. 9, Article ID 04017064, 2017.

[24] X. N. Rong, Analysis of effective stress for saturated soils, Ph.D. thesis, Zhejiang University, Hangzhou, China, 2017.

[25] L.-H. Song, Y. Liu, G.-X. Mei, and J.-M. Zai, "Experimental study on buoyancy effect on deep foundation in clay," Hydrogeology \& Engineering Geology, vol. 35, no. 6, pp. 80-84, 2008.

[26] L. Song, G. Mei, and J. Zai, "Model test on anti-floatation of foundation in clay," Geotechnical Investigation \& Surveying, vol. 6, pp. 26-30, 2008.

[27] G. Mei, L. Song, and J. Zai, "Experimental study on reduction of groundwater buoyancy," Chinese Journal of Geotechnical Engineering, vol. 31, no. 9, pp. 1476-1480, 2009.

[28] B. Han, "Based on unsaturated seepage mechanism of groundwater buoyancy," M.S. thesis, China University of Geosciences (Beijing), Beijing, China, 2013.

[29] L. Song, X. Kang, and G. Mei, "Buoyancy force on shallow foundations in clayey soil: an experimental investigation based on the "Half Interval Search"," Ocean Engineering, vol. 129, pp. 637-641, 2017.

[30] P. Ni, X. Kang, L. Song, G. Mei, and Y. Zhao, "Model tests of buoyant force on underground structures," Journal of Testing and Evaluation, vol. 47, no. 2, pp. 1216-1235, 2019.

[31] Y. Chen, C. Zhou, and H. Zheng, "A numerical solution to seepage problems with complex drainage systems," Computers and Geotechnics, vol. 35, no. 3, pp. 383-393, 2008.

[32] A. A. Ahmed and A. S. Bazaraa, "Three-dimensional analysis of seepage below and around hydraulic structures," Journal of Hydrologic Engineering, vol. 14, no. 3, pp. 243-247, 2009.

[33] P. Ni, G. Mei, and Y. Zhao, "Numerical investigation of the uplift performance of prestressed fiber-reinforced polymer floating piles," Marine Georesources \& Geotechnology, vol. 35, no. 6, pp. 829-839, 2017.

[34] J. Hu and F. Ma, "Comprehensive investigation method for sudden increases of uplift pressures beneath gravity dams: case study," Journal of Performance of Constructed Facilities, vol. 30, no. 5, Article ID 04016023, 2016.

[35] P. Ni, I. D. Moore, and W. A. Take, "Distributed fibre optic sensing of strains on buried full-scale PVC pipelines crossing a normal fault," Géotechnique, vol. 68, no. 1, pp. 1-17, 2018.
[36] P. Ni, G. Mei, and Y. Zhao, "Antiflotation design for water tank using pressure relief technique," Marine Georesources \& Geotechnology, vol. 36, no. 4, pp. 471-483, 2018.

[37] J. Ji, C. Zhang, Y. Gao, and J. Kodikara, "Effect of 2D spatial variability on slope reliability: a simplified FORM analysis," Geoscience Frontiers, vol. 9, no. 6, pp. 1631-1638, 2018.

[38] J. Ji, C. Zhang, Y. Gao, and J. Kodikara, "Reliability-based design for geotechnical engineering: an inverse FORM approach for practice," Computers and Geotechnics, vol. 111, pp. 22-29, 2019.

[39] G. Li, "Some problems about principle of effective stress," Chinese Journal of Geotechnical Engineering, vol. 33, no. 2, pp. 315-320, 2011.

[40] L. Tang, H. Chen, and J. Song, "Process of pore pressure diffusion in saturated clay soil and impact of adsorbed water," Geosciences Journal, vol. 20, no. 5, pp. 649-665, 2016. 


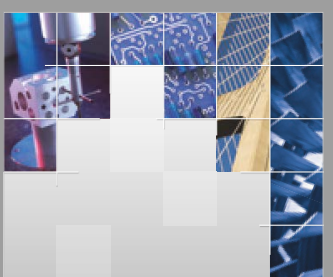

\section{Enfincering}
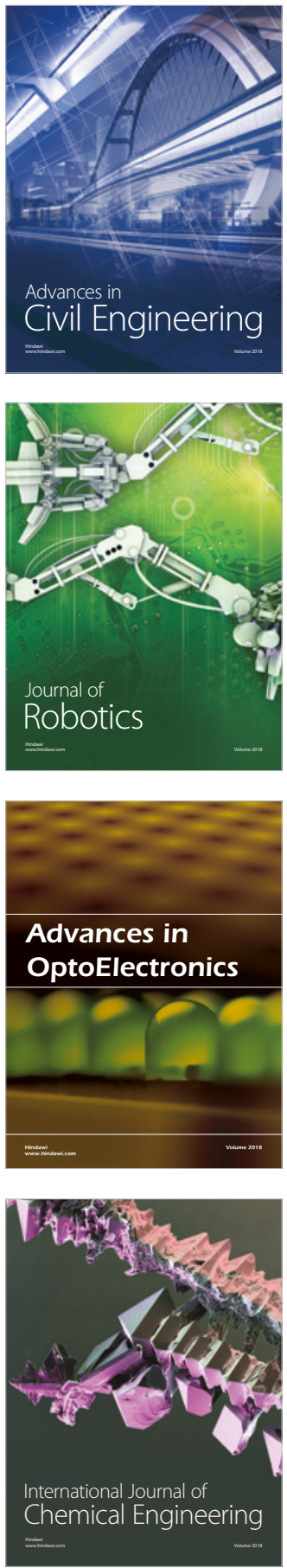

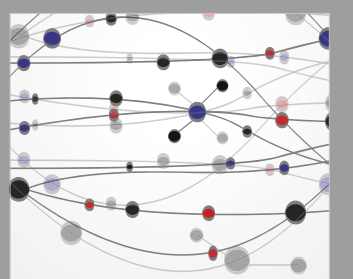

\section{Rotating \\ Machinery}

The Scientific World Journal

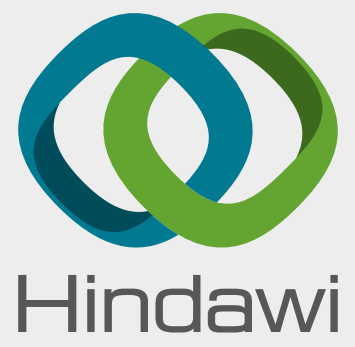

Submit your manuscripts at

www.hindawi.com
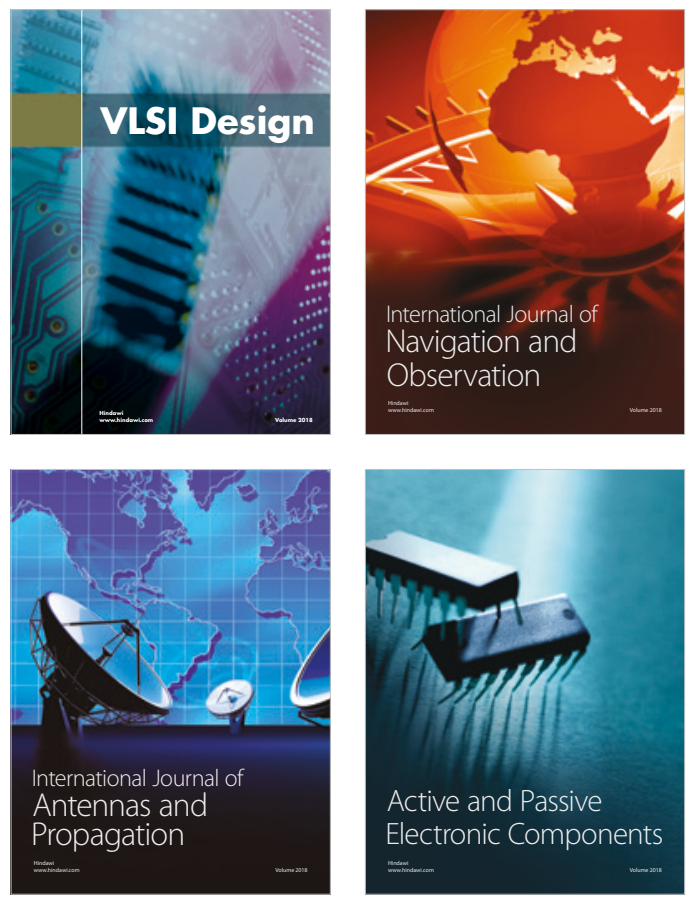
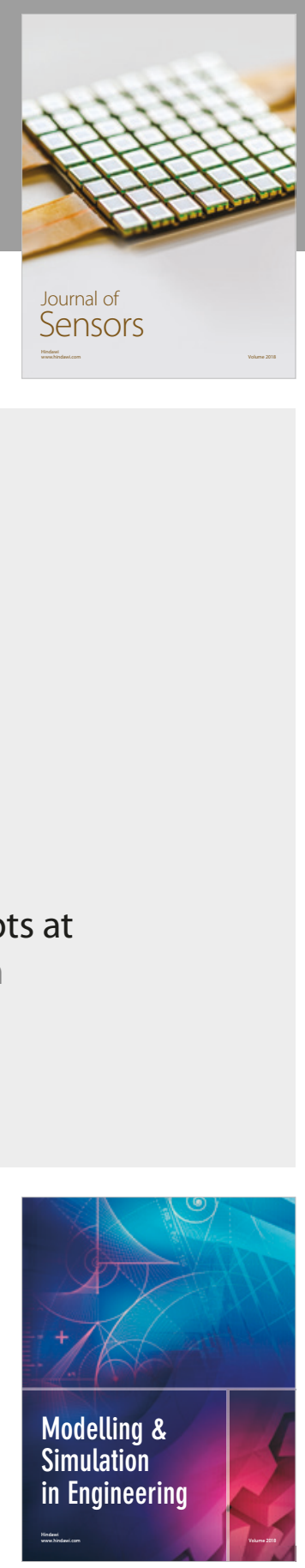

\section{Advances \\ Multimedia}
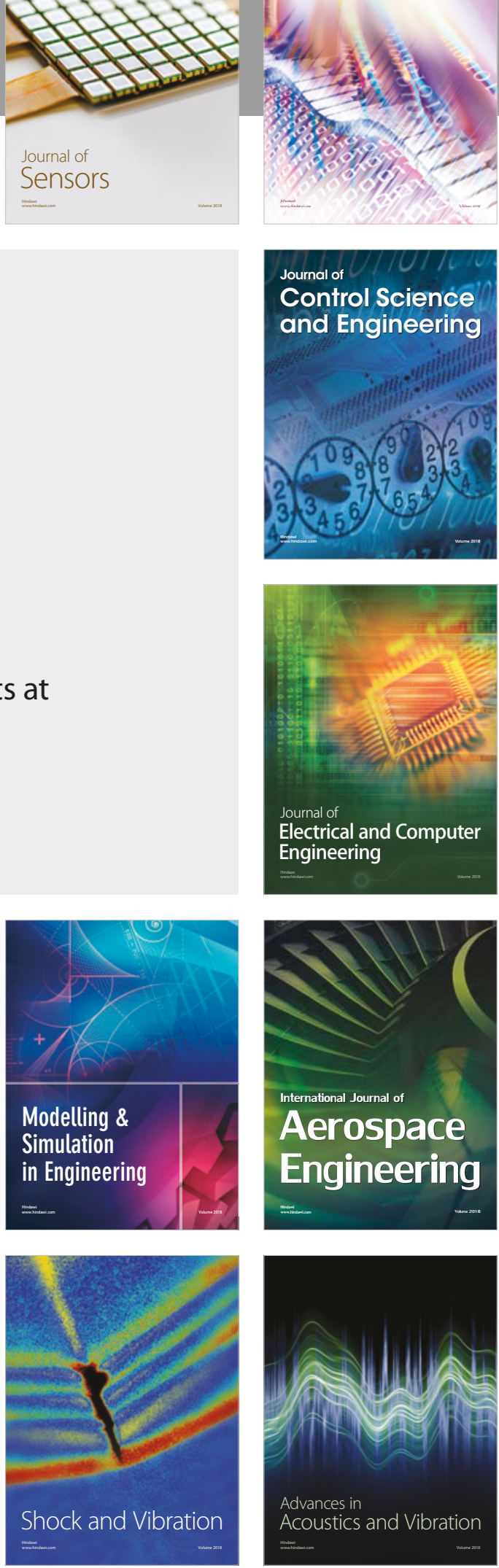